\title{
PROGNOSTIC FACTORS FOR SURVIVAL IN PATIENTS WITH COLORECTAL LIVER METASTASES: experience of a single Brazilian cancer center
}

\author{
Héber Salvador de Castro RIBEIRO'1, Paulo Roberto STEVANATO-FILHO², \\ Wilson Luiz da COSTA Jr. ${ }^{1}$, Alessandro Landskron DINIZ ${ }^{1}$, Paulo HERMAN ${ }^{3}$ and \\ Felipe José Fernández COIMBRA ${ }^{1}$
}

\begin{abstract}
Context - Liver metastases are a common event in the clinical outcome of patients with colorectal cancer and account for $2 / 3$ of deaths from this disease. There is considerable controversy among the data in the literature regarding the results of surgical treatment and prognostic factors of survival, and no analysis have been done in a large cohort of patients in Brazil. Objectives - To characterize the results of surgical treatment of patients with colorectal liver metastases, and to establish prognostic factors of survival in a Brazilian population. Method - This was a retrospective study of patients undergoing liver resection for colorectal metastases in a tertiary cancer hospital from 1998 to 2009. We analyzed epidemiologic variables and the clinical characteristics of primary tumors, metastatic disease and its treatment, surgical procedures and follow-up, and survival results. Survival analyzes were done by the Kaplan-Meier method and the log-rank test was applied to determine the influence of variables on overall and disease-free survival. All variables associated with survival with $P<0.20$ in univariate analysis, were included in multivariate analysis using a Cox proportional hazard regression model. Results - During the period analyzed, 209 procedures were performed on 170 patients. Postoperative mortality in 90 days was $2.9 \%$ and 5 -year overall survival was $64.9 \%$. Its independent prognostic factors were the presence of extrahepatic disease at diagnosis of liver metastases, bilateral nodules and the occurrence of major complications after liver surgery. The estimated 5-year disease-free survival was 39.1\% and its prognostic factors included R1 resection, extrahepatic disease, bilateral nodules, lymph node involvement in the primary tumor and primary tumors located in the rectum. Conclusion - Liver resection for colorectal metastases is safe and effective and the analysis of prognostic factors of survival in a large cohort of Brazilian patients showed similar results to those pointed in international series. The occurrence of major postoperative complications appears to be able to compromise overall survival and further investigation in needed in this topic.
\end{abstract}

HEADINGS - Colorectal neoplasm. Liver neoplasms, secondary. Hepatectomy. Prognosis.

\section{INTRODUCTION}

Liver metastases are a common event in the clinical outcome of patients with colorectal cancer (CRC) and account for two-thirds of deaths from this disease $\mathrm{e}^{(1)}$. Treatment options for this clinical entity include chemotherapy, surgical resection, ablative techniques and more recently, a combination of these modalities ${ }^{(14)}$.

Supported by an adequate selection of patients, resection is the treatment of choice for colorectal liver metastases, since it may provide a cure. In the literature, there are no reports of long-term survival of metastatic patients undergoing systemic therapy exclusively.

Although there are no randomized prospective studies that support the indication for surgery as standard treatment, successive and increasingly numerous institutional and multicenter series have been published in recent decades stating that even with the expanding surgical indications, a gain in overall and disease-free survival could be obtained, reaching a $59 \% 5$-year overall survival ${ }^{(11,12,13)}$.

However, these results deserve a detailed analysis before they are taken as targets because it is extremely

Declared conflict of interest of all authors: none.

'Departamento de Cirurgia Abdominal do Hospital A. C. Camargo; 2 Departamento de Cancerologia Cirúrgica do Hospital A. C. Camargo, São Paulo, SP, Brasil; Departamento de Gastroenterologia da Faculdade de Medicina da Universidade de São Paulo, SP, Brasil.

Correspondence: Dr. Héber Salvador de Castro Ribeiro - Departamento de Cirurgia Abdominal do Hospital A. C. Camargo - Rua Prof. Antônio Prudente, 211 - Liberdade 01509-010 - São Paulo, SP, Brazil. E-mail: hsalvadorcr@gmail.com 
difficult to compare the figures between the various published studies, mainly due to the heterogeneity of patients selected for surgical treatment in each institution, use of multimodal treatment and even the differences in the concepts of survival presented $^{(17)}$.

From these data, more emphasis has been given to selecting patients who tend to have better outcomes with surgical intervention and propose additional or alternative treatments for those with worse prognosis. Thus, many studies have been devoted to assess the impact of several patient characteristics of primary tumors, metastatic disease and its treatment on the results of overall and disease-free survival ${ }^{(2,8,10)}$. An interesting finding is that several variables present themselves differently as prognostic factors in each series. Moreover, regional differences can apparently be involved in the selection of prognostic factors for patients undergoing surgical treatment of colorectal metastases. In Brazil, there are few studies that address the analysis of larger case series that could determine the outcomes of such treatment and its prognostic factors.

\section{Objective}

This study aimed to establish the results of surgical treatment and prognostic factors determining the overall and disease-free survival in patients with liver metastases of colorectal cancer who underwent surgical resection in a Brazilian population.

\section{METHOD}

We conducted a retrospective cohort study including all patients with proven anatomopathologic diagnosis of liver metastases from colorectal cancer who underwent conventional surgery at the Department of Abdominal Surgery, Hospital A. C. Camargo, São Paulo, SP, Brazil, in the period from January 1998 to December 2009. The study was approved by the Institutional Ethical Committee.

The characteristics related to primary tumors were based on anatomopathologic data and pathologic staging following the TNM standardization of the American Joint Committee on Cancer ${ }^{(22)}$. We also analyzed epidemiological variables and the clinical characteristics of metastatic disease and its treatment, surgical procedure, as well as postoperative evolution and survival results. Intraoperative ultrasonography was made in all procedures.

The follow-up routine of patients with colorectal tumors treated at the institution includes quarterly clinic visits in the first 2 years, undergoing laboratory tests for tumor markers, chest radiography and abdominal ultrasound or sectional examinations (CT or MRI) in an alternating fashion. A colonoscopy is repeated annually. From the 3rd to 4th year, this routine is done every 6 months and thereafter annually. Upon the detection of hepatic recurrence of the disease, tests were required in order to establish the extent of metastatic involvement and plan treatment. Positron emission tomography (PET-CT) was required in cases considered as having an increased risk for the presence of extrahepatic disease. Patients were considered eligible for liver resection of colorectal metastases if the lesions fulfilled the criteria of respectability ${ }^{(7)}$ and there was no extrahepatic disease or it could be also treated in a curative intent.

Liver metastases were considered synchronous when detected before, simultaneously or up to 6 months after the diagnosis of the primary tumor and metachronous when this diagnosis occurred after this period. Patients were considered as having extrahepatic disease when imaging or surgical procedures showed metastatic foci in organs other than the liver.

Surgical morbidity was defined as any deviation from the normal postoperative course not expected for a surgical procedure ${ }^{(9)}$ while postoperative mortality comprised of deaths attributable to hepatectomy that occurred in the interval between the end of the surgical procedure and the first 90 postoperative days.

We chose to employ a classification of surgical complications $^{(6)}$ to group them by their clinical repercussions and need for therapeutic intervention (Figure 1).

FIGURE 1. Clavien et al ${ }^{(6)}$ classification of surgical complications

\begin{tabular}{|cl|}
\hline Complication grade & \multicolumn{1}{c|}{ Definition } \\
\hline Grade 1 & $\begin{array}{l}\text { Any deviation from the expected } \\
\text { postoperative course that does not require } \\
\text { specific treatment } \\
\text { Complications requiring drug therapy, blood } \\
\text { transfusions or nutritional support } \\
\text { Grade 2 }\end{array}$ \\
Grade 3 & $\begin{array}{l}\text { Postoperative changes that require invasive } \\
\text { treatment (puncture, drainage and re- } \\
\text { operations) } \\
\text { Grade } 4\end{array}$ \\
Grade 5 & $\begin{array}{l}\text { and need for intensive care } \\
\text { Postoperative death }\end{array}$ \\
\hline
\end{tabular}

For statistical analysis, the software Statistical Package for Social Science (SPSS) version 20.0 was used. The relationship of prognostic factors was evaluated with Pearson's chi-square test or chi-square two-tailed corrected (Fisher's exact test) as indicated, followed by multivariate analysis by Cox regression. Results were considered significant with $P<0.05$. Survival analyzes were done by the Kaplan-Meier method and the log-rank test was applied to determine the influence of variables on overall and disease-free survival. All variables associated with survival with $P<0.20$ in univariate analysis were included in multivariate analysis using a Cox proportional hazard regression model.

\section{RESULTS}

During this period, 209 resections were performed on 170 patients. These patients were predominantly male $(53.5 \%)$ with a median age of 59 years (23-80 years). Postoperative mortality in 90 days was $2.9 \%$. With a median follow-up time of 29 months (12-120 months), the estimated overall survival was $90.1 \%$ at 1 year, $69.6 \%$ at 3 years and $64.9 \%$ at 5 years. The median overall survival was 88 months. The estimated 


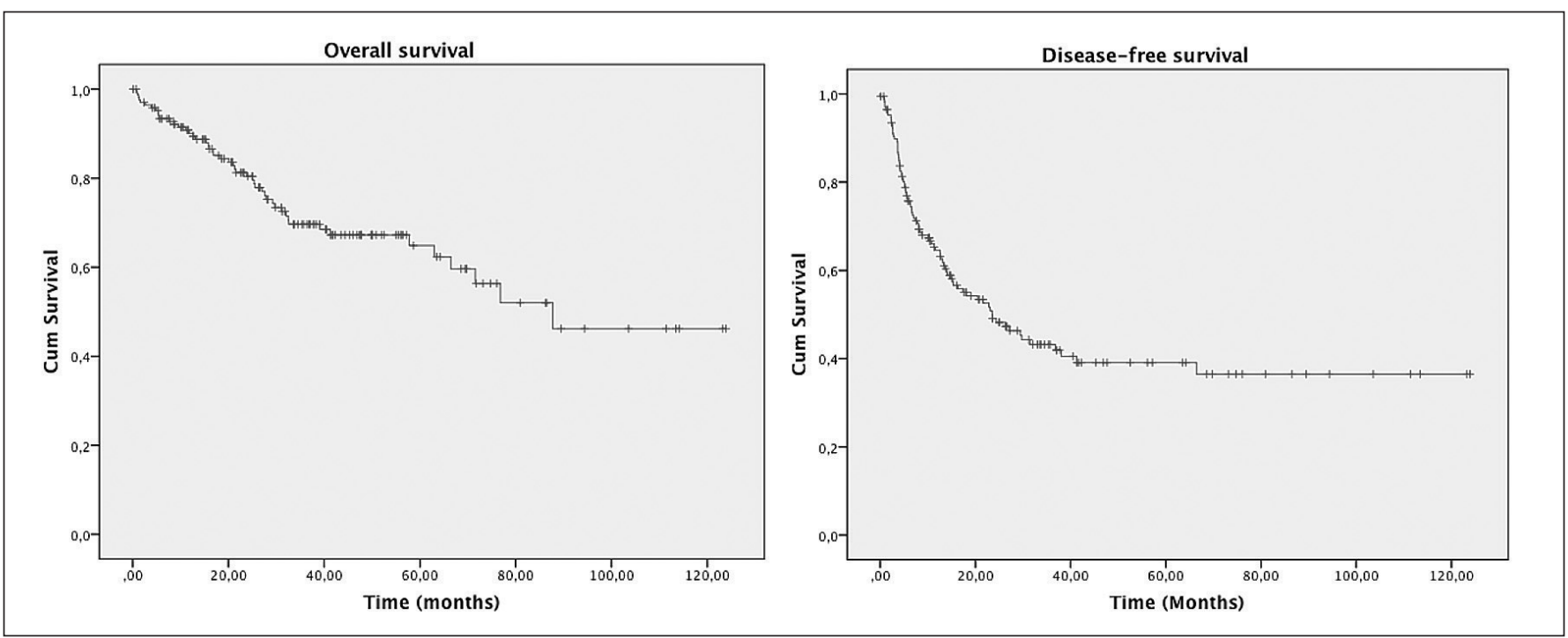

FIGURE 2. Kaplan-Meier curves of overall and disease-free survival in 170 patients undergoing surgical treatment of liver metastases from colorectal cancer

5 -year disease-free survival was $39.1 \%$ with a median of 24 months (Figure 2).

In univariate analysis, the presence of extrahepatic disease, bilateral liver nodules, more than three nodules, the size of the largest nodule greater than $4 \mathrm{~cm}, \mathrm{R} 1$ resection, adjuvant chemotherapy after hepatectomy and the occurrence of more severe postoperative complications (grade 3 and 4) in the Clavien classification were predicting factors of worse overall survival (Table 1, Figure 3 ).

Factors related to worse disease-free survival in univariate analysis were T3/T4 primary tumors, lymph node involvement in the primary tumor and rectum as its primary site, extrahepatic disease concomitant to metastases in the liver, bilateral nodules, more than three metastases, $\mathrm{R} 1$ resection and close resection margins up to $1 \mathrm{~mm}$ and carcinoembryonic antigen (CEA) level above $100 \mathrm{ng} / \mathrm{mL}$ for the diagnosis of liver metastases (Table 1, Figure 2).

As shown in Table 1, without reaching statistical significance, a worse disease-free survival was also noted for patients with synchronous hepatic metastases, liver recurrence less than 12 months after primary tumor surgery, postoperative blood transfusion, number of resected segments greater than three nodules and tumors with more than $4 \mathrm{~cm}$.

In the multivariate analysis by Cox regression, extrahepatic recurrence concomitant with hepatic metastases, bilateral nodules and Clavien classification grade 3 and 4 surgical complications persisted as independent prognostic factors for worse overall survival (Table 2, Figure 3).

Table 3 shows the multivariate analysis of prognostic factors for disease-free survival. The independent prognostic factors of recurrence after hepatectomy were $\mathrm{R} 1$ resection, the presence of extrahepatic disease, bilateral nodules, lymph node involvement in the primary tumor and rectum as the primary tumor site (Figure 4).

\section{DISCUSSION}

In this sample of patients, estimated 5-year overall survival was $64.9 \%$, a higher result than that found in other principal studies so $\operatorname{far}^{(4,11,12,21)}$. This can be explained by the relatively short median follow-up time (29 months) and the extremely rigorous selection of patients submitted to surgical resection, especially in the 1st years of the study. Still, it is positioned as a significant result, since other studies with similar or even lower follow-up periods showed worse overall survival ${ }^{(5,23)}$.

Prognostic factors significantly correlated with overall survival included features that can be attributed to the pattern of dissemination, the burden of metastatic disease present at the time of surgery and the postoperative course. Thus, patients with extrahepatic disease represent an extract of the cases where the spread of tumor cells follow different pathways of ascent in the bloodstream through the hepatic portal system and therefore have a worse prognosis.

Likewise, the presence of bilateral nodules, more than three nodules and the diameter of the largest nodule above $4 \mathrm{~cm}$ are clinical characteristics that distinguished the group of patients with a greater amount of metastatic disease, which appears to be the concept actually involved in the worse prognosis of survival observed. Similar results were found in other stu$\operatorname{dies}^{(12,16,19)}$. There is a probable correlation of these data with the presence of extrahepatic disease, since in the multivariate analysis only bilaterality remained as a prognostic factor, perhaps because it has influence on other characteristics related to worse outcomes, such as resection margin and the presence of clinically significant postoperative complications ${ }^{(12,16,19)}$.

The occurrence of grade 3 and 4 postoperative complications of the Clavien classification proved to be an isolated prognostic factor for overall survival in this series 
TABLE 1. Univariate analysis of prognostic factors for overall survival (OS) and disease-free survival (DFS) in 170 cases of liver metastases from colorectal cancer

\begin{tabular}{|c|c|c|c|c|c|}
\hline Variable & $\mathrm{n}$ & 5 -yr OS (\%) & $P$ & 5-yr DFS (\%) & $P$ \\
\hline \multicolumn{6}{|l|}{ Primary site } \\
\hline Colon & 130 & $69 \%$ & \multirow[t]{2}{*}{0.232} & $45.2 \%$ & \multirow[t]{2}{*}{0.039} \\
\hline Rectum & 40 & $56.1 \%$ & & $20.9 \%$ & \\
\hline \multicolumn{6}{|l|}{ T stage of primary } \\
\hline $\mathrm{T} 1-\mathrm{T} 2$ & 24 & $71.4 \%$ & \multirow[t]{2}{*}{0.344} & $56.0 \%$ & \multirow[t]{2}{*}{0.036} \\
\hline T3-T4 & 125 & $62.1 \%$ & & $36.3 \%$ & \\
\hline \multicolumn{6}{|l|}{$\mathrm{N}$ stage of primary } \\
\hline No & 54 & $75.1 \%$ & \multirow[t]{2}{*}{0.141} & $54.8 \%$ & \multirow[t]{2}{*}{0.008} \\
\hline $\mathrm{N}_{+}$ & 91 & $59.3 \%$ & & $30.0 \%$ & \\
\hline \multicolumn{6}{|l|}{ Hepatic recurrence } \\
\hline Synchronous & 89 & $70.6 \%$ & \multirow[t]{2}{*}{0.162} & $32.3 \%$ & \multirow[t]{2}{*}{0.214} \\
\hline Metachronous & 81 & $59.9 \%$ & & $46.0 \%$ & \\
\hline \multicolumn{6}{|l|}{ Recurrence site } \\
\hline Hepatic & 144 & $68.9 \%$ & \multirow[t]{2}{*}{0.001} & $45.4 \%$ & \multirow[t]{2}{*}{$<0.001$} \\
\hline Hepatic + extrahepatic & 26 & 39.2 & & $7.5 \%$ & \\
\hline \multicolumn{6}{|l|}{ Bilateral disease } \\
\hline Yes & 70 & $47.4 \%$ & \multirow[t]{2}{*}{$<0.001$} & $17.3 \%$ & \multirow[t]{2}{*}{$<0.00$} \\
\hline No & 100 & $76.2 \%$ & & $53.0 \%$ & \\
\hline \multicolumn{6}{|c|}{ Adjuvant chemotherapy after hepatectomy } \\
\hline Yes & 112 & $69.2 \%$ & \multirow{2}{*}{0.016} & $39.0 \%$ & 0.105 \\
\hline No & 52 & $51.2 \%$ & & $37.0 \%$ & \\
\hline Number of nodules & & & & & \\
\hline 1-2 nodules & 105 & $71.0 \%$ & 0.007 & $50.1 \%$ & $<0.001$ \\
\hline$\geq 3$ & 64 & $55.6 \%$ & & $17.7 \%$ & \\
\hline $\operatorname{CEA}(n g / m L)(n=148)$ & & & & & \\
\hline$\leq 100$ & 116 & $67.7 \%$ & 0.098 & $42.9 \%$ & 0.008 \\
\hline$>100$ & 32 & $43.1 \%$ & & $24.5 \%$ & \\
\hline Size of largest nodule $(\mathrm{cm})$ & & & & & \\
\hline$\leq 4.0$ & 93 & $70.0 \%$ & 0.024 & $41.3 \%$ & 0.054 \\
\hline$>4.0$ & 72 & $58.1 \%$ & & $35.5 \%$ & \\
\hline Number of resected segments & & & & & \\
\hline$<3$ & 77 & $61.3 \%$ & 0.946 & $42.2 \%$ & 0.185 \\
\hline$\geq 3$ & 93 & $68.2 \%$ & & $36.4 \%$ & \\
\hline Disease-free interval (months) & & & & & \\
\hline$\leq 12$ & 108 & $70.0 \%$ & 0.216 & $32.9 \%$ & 0.096 \\
\hline$>12$ & 62 & $57.3 \%$ & & $50.1 \%$ & \\
\hline Resection margin & & & & & \\
\hline R0 & 156 & $67.5 \%$ & 0.014 & $40.7 \%$ & 0.002 \\
\hline $\mathrm{R} 1$ & 11 & $35.1 \%$ & & $18.2 \%$ & \\
\hline Size of resection margin $(n=114)$ & & & & & \\
\hline $1 \mathrm{~mm}$ & 19 & $88.4 \%$ & 0.113 & $17.2 \%$ & 0.035 \\
\hline $2-9 \mathrm{~mm}$ & 55 & $65.9 \%$ & & $43.4 \%$ & \\
\hline$\geq 10 \mathrm{~mm}$ & 40 & $81.3 \%$ & & $53.6 \%$ & \\
\hline Postoperative complications $(\mathrm{n}=170)$ & & & & & \\
\hline Without complications/grade 1 and 2 & 125 & $70.1 \%$ & $<0.001$ & $38.8 \%$ & 0.161 \\
\hline Complications/grade 3 and 4 & 45 & $50.2 \%$ & & $44.1 \%$ & \\
\hline Blood transfusion & & & & & \\
\hline Yes & 54 & $62.7 \%$ & 0.313 & $30.5 \%$ & 0.062 \\
\hline No & 115 & $66.2 \%$ & & $44.1 \%$ & \\
\hline Rehepatectomy & & & & & \\
\hline Yes & 34 & $82.1 \%$ & 0.136 & $34.9 \%$ & 0.257 \\
\hline No & 136 & $60.4 \%$ & & $40.7 \%$ & \\
\hline
\end{tabular}




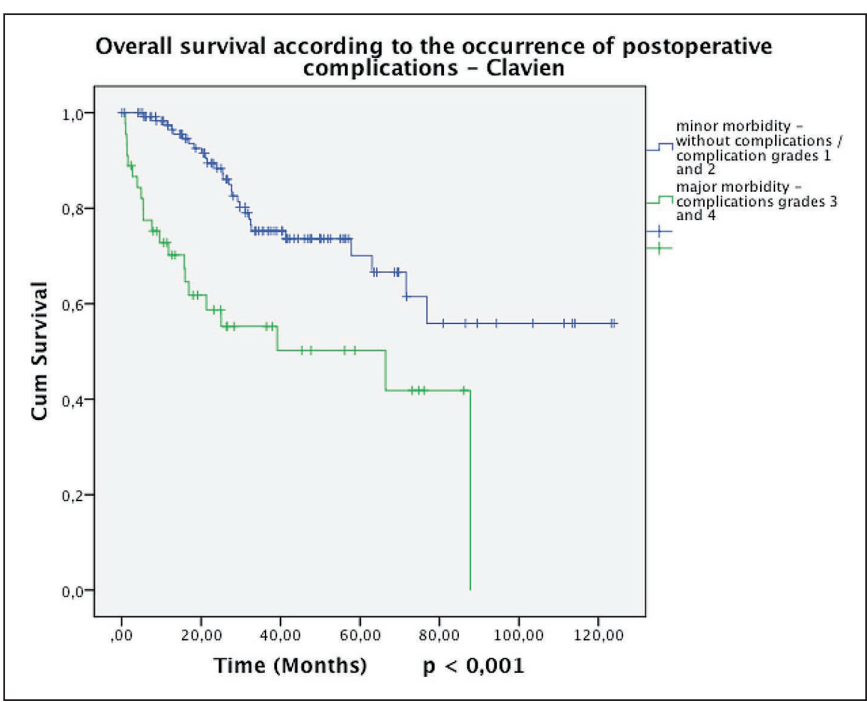

FIGURE 3. Overall survival and postoperative complications according with the Clavien classification (minor morbidity - without complications/ complication grades 1 and 2; major morbidity - complications grades 3 and 4)

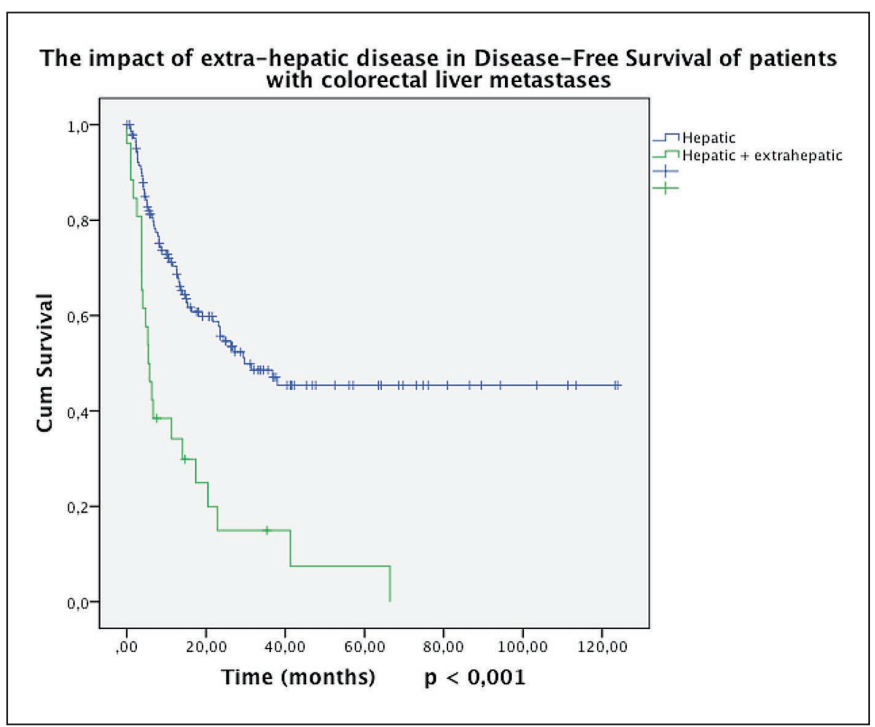

FIGURE 4. The impact of extra-hepatic disease in disease-free survival of patients with colorectal liver metastases

TABLE 2. Multivariate analysis of prognostic factors for overall survival (OS) in 170 cases of liver metastases from colorectal cancer

\begin{tabular}{|c|c|c|c|}
\hline Variable & $\mathrm{HR}^{*}$ & $P$ & CI $95 \% * *$ \\
\hline \multicolumn{4}{|l|}{ Recurrence site } \\
\hline Hepatic & 1.0 & \multirow{2}{*}{0.021} & \multirow{2}{*}{$1.16 \pm-6.25$} \\
\hline Hepatic + extrahepatic & 2.6 & & \\
\hline \multicolumn{4}{|l|}{ Bilateral disease } \\
\hline No & 1.0 & \multirow{2}{*}{0.003} & \multirow{2}{*}{$1.68-12.7$} \\
\hline Yes & 4.6 & & \\
\hline \multicolumn{4}{|l|}{ Postoperative complications } \\
\hline Without complications / grade 1 and 2 & 1.0 & \multirow{2}{*}{0.027} & \multirow{2}{*}{$1.12-6.60$} \\
\hline Complications / grade 3 and 4 & 2.7 & & \\
\hline
\end{tabular}

*HR (hazard ratio);

$* * \mathrm{CI} 95 \%(95 \%$ confidence interval)

TABLE 3. Multivariate analysis of prognostic factors for disease-free survival (DFS) in 170 cases of liver metastases from colorectal cancer

\begin{tabular}{|c|c|c|c|}
\hline Variable & $\mathrm{HR}^{*}$ & $P$ & CI $95 \% * *$ \\
\hline \multicolumn{4}{|l|}{ Resection margin } \\
\hline R0 & 1.0 & \multirow{2}{*}{$<0.001$} & \multirow{2}{*}{$6.92-16.9$} \\
\hline $\mathrm{R} 1$ & 6.9 & & \\
\hline \multicolumn{4}{|l|}{ Recurrence site } \\
\hline Hepatic & 1.0 & \multirow{2}{*}{$<0.001$} & \multirow{2}{*}{$2.98-9.06$} \\
\hline Hepatic + extrahepatic & 5.2 & & \\
\hline \multicolumn{4}{|l|}{ Bilateral disease } \\
\hline No & 1.0 & \multirow{2}{*}{$<0.001$} & \multirow{2}{*}{$2.16-5.93$} \\
\hline Yes & 3.5 & & \\
\hline \multicolumn{4}{|l|}{$\mathrm{N}$ stage of primary } \\
\hline No & 1.0 & \multirow{2}{*}{0.001} & \multirow{2}{*}{$1.50-4.88$} \\
\hline $\mathrm{N}+$ & 2.7 & & \\
\hline \multicolumn{4}{|l|}{ Primary site } \\
\hline Colon & 1.0 & \multirow{2}{*}{0.046} & \multirow{2}{*}{$1.00-2.79$} \\
\hline Rectum & 1.6 & & \\
\hline
\end{tabular}

* HR (hazard ratio)

$* *$ CI $95 \%(95 \%$ confidence interval) 
of patients, as also observed in other studies using similar criteria $^{(15,20)}$. However, in our study there was no negative impact of postoperative complications in disease-free survival. Thus, this finding may be related to the compromise of other organs and systems resulting from complications occurring after resection of hepatic metastases and not correlated with tumor progression. This demonstrates that the optimization of surgical treatment to reduce clinical complications can contribute to greater overall survival.

The estimated disease-free survival for this study at 5 years was $39.1 \%$, similar to data found in some large studies in the literature ${ }^{(5,17)}$ and supported by the finding of a recurrence rate of $61.1 \%$. It is noteworthy that some patients with hepatic recurrence could undergo further resection with numerically higher overall survival $(82.1 \%$ versus $60.4 \%)$ but without statistical significance (Table 1).

The analysis of prognostic factors for disease-free survival revealed that a greater number of characteristics were significantly correlated with this outcome when compared with the data of overall survival. This finding supports the idea of recurrence being a complex and multifactorial event. Without a doubt, the great challenge to be overcome in the treatment of liver metastases from colorectal cancer, beyond achieving resectability, is how to inhibit disease recurrence after an apparently complete resection.

In this study, the factors with greater predictive capacity of recurrence after liver resection from colorectal metastases were compromised microscopic margin of resection (R1) and the presence of extrahepatic disease. The inclusion of the resection margin in this analysis can be considered controversial, since, in practice, patients with compromised resection margins do not present disease-free intervals ${ }^{(12)}$. However, the data of studies with strict control of the resection margins show that although such patients have lower rates of disease-free survival, recurrence does not occur more frequently in the resection margin (probable site of residual disease), but in other parts of the liver or other organs $s^{(3,18,20)}$.

Regarding the presence of extrahepatic disease at diagnosis, it is understandable that the pattern of dissemination does in fact strongly contribute to the emergence of new foci of disease after surgery.

The bilateral disease was also an adverse independent prognostic factor for disease-free survival, with a 3.5-time higher risk of recurrence. As already discussed, this is an indirect measure of the burden of metastatic disease and reflects the weight that this factor has on treatment outcomes.

Some data related to the primary tumor remained as independent prognostic factors for recurrence, including lymph node compromise and the rectum as primary site. Such characteristics are indeed classic prognostic factors of survival in colorectal cancer and it is interesting that they are still engaged in this role also in metastatic disease. Lymph node involvement translates, in practice, to another route in the spread of cancer, while the primary site in the rectum is associated with a distinct pattern of systemic dissemination, increasing the chances of metastatic occurrence in other sites besides the liver ${ }^{(19,24)}$.

Thus, we concluded that liver resection for colorectal metastases is safe and effective in a cohort of Brazilian patients, with demonstrated survival rates that accompany the best results published in the international literature. The occurrence of major postoperative complications appears to be able to compromise overall survival and further investigation in needed in this topic.

\section{ACKNOWLEDGEMENT}

To Dr. André Luiz Godoy, also coworker in this study.

Ribeiro HSC, Stevanato-Filho PR, Costa Jr. WL, Diniz AL, Herman P, Coimbra FJF. Fatores prognósticos de sobrevida em pacientes com metástases hepáticas colorretais. Arq Gastroenterol. 2012;49(4):266-72.

RESUMO - Contexto - As metástases hepáticas são evento comum na evolução clínica de pacientes com câncer colorretal e são responsáveis por $2 / 3$ dos óbitos por esta doença. Há grande controvérsia entre os dados publicados na literatura quanto a resultados de tratamento cirúrgico e seus fatores prognósticos e não há análise, em casuísticas maiores, destes aspectos em uma grande coorte de pacientes no Brasil. Objetivos - Caracterizar os resultados do tratamento cirúrgico de pacientes com metástases hepáticas de tumores colorretais e estabelecer os fatores prognósticos de sobrevida em uma população. Método - Estudo retrospectivo de pacientes submetidos a ressecção hepática de metástases colorretais em hospital oncológico terciário, de 1998 a 2009. Foram analisadas variáveis epidemiológicas e dos tumores primários da doença metastática e seu tratamento, dos procedimentos cirúrgicos e do seguimento e os resultados de sobrevidas. Para as análises de sobrevida foram utilizadas as curvas de Kaplan-Meyer e o teste de log-rank foi aplicado para determinar a influência das variáveis estudadas nas sobrevidas global e livre de doença. Aquelas variáveis em que este teste apresentou $P<0,20$ em análise univariada, foram incluídas em análise multivariada pelo modelo de regressão de Cox. Resultados - No período analisado, 209 procedimentos foram realizados em 170 pacientes. A mortalidade em 90 foi de 2,9\%. A sobrevida global em 5 anos foi de $64,9 \%$. Os fatores prognósticos independentes de sobrevida global foram a presença de doença extra-hepática no momento do diagnóstico das metástases hepáticas, de nódulos em ambos os lobos hepáticos e a ocorrência de complicações maiores após a cirurgia. A sobrevida livre de doença estimada em 5 anos foi de 39,1\% e seus fatores prognósticos incluíram a ressecção R1, a presença de doença extra-hepática, doença bilobar, a presença de acometimento linfonodal no tumor primário e tumores primários localizados no reto. Conclusão - A ressecção de metástases hepáticas de câncer colorretal se demonstrou segura e eficaz em nosso meio, com resultados semelhantes aos apresentados por outras grandes séries internacionais. A ocorrência de complicações pós-operatórias parece poder comprometer os resultados de sobrevida global obtidos e investigação mais aprofundada se faz necessária neste sentido.

DESCRITORES - Neoplasias colorretais. Neoplasias hepáticas, secundárias. Hepatectomia. Prognóstico. 


\section{REFERENCES}

1. Adam R. Chemotherapy and surgery: new perspectives on the treatment of unresectable liver metastases. Ann Oncol. 2003;14 Suppl 2:ii13-6.

2. Adson MA, van Heerden JA, Adson MH, Wagner JS, Ilstrup DM. Resection of hepatic metastases from colorectal cancer. Arch Surg. 1984;119:647-51.

3. Are C, Gonen M, Zazzali K, Dematteo RP, Jarnagin WR, Fong Y, Blumgart LH, D'Angelica M. The impact of margins on outcome after hepatic resection for colorectal metastasis. Ann Surg. 2007;246:295-300.

4. Chedid AD, Villwock Mde M, Chedid MF, Rohde L. Fatores prognósticos na ressecção de metástases hepáticas de câncer colorretal. Arq Gastroenterol. 2003;40:159-65.

5. Choti MA, Sitzmann JV, Tiburi MF, Sumetchotimetha W, Rangsin R, Schulick RD, Lillemoe KD, Yeo CJ, Cameron JL. Trends in long-term survival following liver resection for hepatic colorectal metastases. Ann Surg. 2002;235:759-66.

6. Clavien PA, Sanabria JR, Strasberg SM. Proposed classification of complication of surgery with examples of utility in cholecystectomy. Surgery. 1992;111:518-26.

7. Coimbra FJ, Pires TC, Costa Junior WL, Diniz AL, Ribeiro HS. Advances in surgical treatment of colorectal liver metastases. Rev Assoc Med Bras. 2011;57:220-7.

8. Coppa GF, Eng K, Ranson JH, Gouge TH, Localio SA. Hepatic resection for metastatic colon and rectal cancer. An evaluation of preoperative and postoperative factors. Ann Surg. 1985;202:203-8.

9. Dindo D, Demartines N, Clavien PA. Classification of surgical complications - a new proposal with evaluation in a cohort of 6336 patients and results of a survey. Ann Surg. 2004;240:205-13.

10. Doci R, Gennari L, Bignami P, Montalto F, Morabito A, Bozzetti F. One hundred patients with hepatic metastases from colorectal cancer treated by resection: analysis of prognostic determinants. Br J Surg. 1991;78:797-801.

11. Fernandez FG, Drebin JA, Linehan DC, Dehdashti F, Siegel BA, Strasberg SM Five-year survival after resection of hepatic metastases from colorectal cancer in patients screened by positron emission tomography with F-18 fluorodeoxyglucose (FDG-PET). Ann Surg. 2004;240:438-47.

12. Fong Y, Fortner J, Sun RL, Brennan MF, Blumgart LH. Clinical score for predicting recurrence after hepatic resection for metastastic colorectal cancer: analysis of 1001 consecutive cases. Ann Surg. 1999;230:309-21.
13. Foster JH. Survival after liver resection for secondary tumors. Am J Surg. 1978; 135:389-94

14. Khatri VP, Chee KG, Petrelli NJ. Modern multimodality approach to hepatic colorectal metastases: solutions and controversies. Surg Oncol. 2007;16:71-83.

15. Laurent C, Sa Cunha A, Couderc P, Rullier E, Saric J. Influence of postoperative morbidity on long-term survival following liver resection for colorectal metastases. Br J Surg. 2003;90:1131-6.

16. Malik HZ, Prasad KR, Halazun KJ, Aldoori A, Al-Mukhtar A, Gomez D, Lodge JP, Toogood GJ. Preoperative prognostic score for predicting survival after hepatic resection for colorectal liver metastases. Ann Surg 2007;246:806-14.

17. Memon MA, Beckingham IJ. Surgical resection of colorectal liver metastases. Colorectal Dis. 2001;3:361-73.

18. Pawlik TM, Scoggins CR, Zorzi D, Abdalla EK, Andres A, Eng C, Curley SA, Loyer EM, Muratore A, Mentha G, Capussotti L, Vauthey JN. Effect of surgical margins status on survival and site of recurrence after hepatic resection of colorectal metastases. Ann Surg. 2005;241:715-22.

19. Rees M, Tekkis PP, Welsh FK, O'Rourke T, John TG. Evaluation of long-term survival after hepatic resection for metastatic colorectal cancer: a multifactoria model of 929 patients. Ann Surg. 2008;247:125-35.

20. Schiesser M, Chen JWC, Maddern GJ, Padbury RT. Perioperative morbidity affects long-term survival in patients following liver resection for colorectal metastases. J Gastrointest Surg. 2008;12:1054-60.

21. Scoggins CR, Campbell ML, Landry CS, Slomiany BA, Woodall CE, McMasters KM, Martin RC. Preoperative chemotherapy does not increase morbidity or mortality of hepatic resection for colorectal cancer metastases. Ann Surg Oncol 2009; 16:35-41.

22. Sobin LH, Wittekind CH. Cólon e reto in TNM Classificação de tumores malignos. $6^{\mathrm{a}}$ ed. Rio de Janeiro: INCA; 2002. p.77-81.

23. Stewart GD, O’Súilleabháin CB, Madhavan KK, Wigmore SJ, Parks RW, Garden OJ. The extent of resection influences outcome following hepatectomy for colorectal liver metastases. Eur J Surg Oncol. 2004;30:370-6.

24. Zakaria S, Donohue JH, Que FG, Farnell MB, Schleck CD, Ilstrup DM, Nagorney DM. Hepatic resection for colorectal metastases: value for risk scoring systems. Ann Surg. 2007;246:183-91.

Received 20/6/2011 Accepted 22/8/2012. 